\title{
Impact of Variety Type and Irrigation on Technical Efficiency of Potato Farmers: The Case of Terai Region of Nepal
}

Surya Prasad Adhikari ( $\nabla$ adhikarisurya56@gmail.com )

Nepal Agricultural Research Council https://orcid.org/0000-0002-2712-9387

\section{Yuga Nath Ghimire}

Nepal Agricultural Research Council

Krishna Prasad Timsina

Nepal Agricultural Research Council

Samaya Gairhe

Nepal Agricultural Research Council

\section{Research}

Keywords: Coefficient, Determinants, Efficiency, Empirical, Technical

Posted Date: August 11th, 2020

DOI: https://doi.org/10.21203/rs.3.rs-55416/v1

License: (9) This work is licensed under a Creative Commons Attribution 4.0 International License. Read Full License 


\section{Abstract}

The national average potato productivity is far below as compared to other neighbouring countries due to several production constraints. Variety and irrigation are the important factors to increase production.

The aim of this study is to find the technical efficiency of potato production and to estimate the impact of variety type and irrigation on technical efficiency. A multistage random sampling procedure was employed to select 300 potato farmers from three districts of Nepal. The study used a stochastic frontier production function model to find the production elasticity coefficients of inputs, determinants of efficiency, and technical efficiency of potato farmers. Results showed that variety type and irrigation have a significant positive impact on the technical efficiency of potato production. Nepalese improved varieties adopter farmers were more efficient (73\%) than Indian (66\%) and local (59\%) potato varieties. Likewise, Irrigated potato farming has higher efficiency $(71 \%)$ than rainfed potato $(61 \%)$ farming. The mean technical efficiency value of potato farmers was 69 per cent and farmers can increase it with better use of available resources. It is suggested that use of improved potato varieties and irrigation application along with proper amounts of inputs used help to improve technical efficiency of potato farmers.

\section{Introduction}

Potato is a staple food of High hills whereas it is used as a major vegetable crop in the Terai and Mid hills of Nepal. Nepalese farmers have been cultivating potatoes for over 200 years and it is one of the important crops to address the problem of food insecurity because it has a great potential to grow yearround in the country. Potato production plays an important role in the economy of Nepal. It accounts for $42.46 \%$ in the total vegetable cropped area of Nepal providing economic benefits as well as creating employment opportunities for the rural farmers. The area under this crop is 195173 ha with a production of $2881829 \mathrm{mt}$. The national average productivity of potato is $14.76 \mathrm{mt} / \mathrm{ha}$ (MoALD 2019).

The productivity of potato is far below as compared to neighbouring countries India and China 22.56 and $18.76 \mathrm{mt} /$ ha respectively. In 2017, Nepal imported 290804 mtpotatoes with a value of $\$ 43063000$. The import has been increased more than 6 times over 10 years of period (FAOSTAT 2018). Although the annual growth rate of potato productivity was 1.76 percent per annum in the last 17 years, the gap between potential yield and farm-level production is still very high (Timsina et al. 2019). The Lower level of production is associated with the poor adoption of agricultural technologies, inefficient use of resources such as land and fertilizer, and lack of research (Adhikari and Bjorndal 2012; Bhattarai et al. 2015). There are various technical, environmental, and socioeconomic factors contributing to low potato production in Nepal. To substitute the import of potato, it is necessary to increase production through improvements in potato production efficiency. To increase the efficiency of potato farmers, it is important to know the causes of the inefficient use of resources. Improving efficiency in production allows farmers to increase their output without additional inputs and changing production technologies resulting in increased productivity (Bravo-Uretra and Pinheiro 1997). In general, resources in the agricultural sector, especially in under-developed countries are being utilized inefficiently (Ahmad et al. 2006). Potato productivity and efficiency may be affected by various farm-specific factors such as variety types, 
amount of fertilizer and seeds, labor use, irrigation condition, farm size, family size, credit accessibility to farmers, technical support, education level of household head, land type, land use pattern, etc. Technical efficiency is the capacity of a farm to produce an optimum quantity of output with the given level of inputs. The productivity of potatoes could be improved by increasing the production efficiency of smallholder farmers. To increase the productivity of smallholder farmers more efficient use of inputs is necessary.

Several studies have been conducted about potato productivity and technical inefficiency of potato production in developing countries. Amara et al. (1999) analyzed the technical efficiency among potato farmers and examined the farmers' attitude towards technological innovation. Wilson (1998) in the UK found that the positive impact of irrigation facilities and the storage of potato after harvest on technical efficiency while experience in potato farming, small scale potato farming, and chitting of seed potatoes were negative to the technical efficiency. Galabadaet al. (2014) in Sri Lanka found that there are opportunities in improving resource use efficiency in potato farming. Barasaet. al. (2019) in Kenya reported that the mean technical efficiency of potato farmers was estimated at $65 \%$. They found that technical efficiency was positively influenced by the age of the farmer, education years, farming experience, frequency of extension services, and land size, whereas negatively influenced by household size.

Study on technical efficiency of potato farmers in Nepal is very limited, whilst the majority of the research focused on adoption-related issues.A study conducted in Eastern Hill of Nepal revealed that the improved seed had a positive impact onvegetable production efficiency (Shrestha et al. 2015). Enhancing adoption of improved potato varieties could impact on farmer's income, household food, and nutritional security (Gairhe et al. 2017). Shrestha et al. (2015) found that farm-specific factors such as seed types, credit access, and technical support significantly affected inefficiency in vegetable production. Furthermore, policies need to focus on innovating and adopting improved seed varieties, easy access to credit facilities, and technical support and backstopping to farmers.

Improved variety is one of the important factors to increase the efficiency of potato farmers. In Nepal, farmers are cultivating Nepalese improved, Indian, and local potato varieties.Till date, Nepal Agricultural Research Council (NARC) has released eleven and registered five potato varieties. These varieties have large yield potential and the adoption of these varieties can greatly enhance national potato production (Kafle and Shah 2012). Moreover, improved varieties have high yield potential and diffusion of these technologies can greatly enhance national potato production (Tufa et al. 2015). No studies have been conducted on the impact of Nepalese improved potato varieties on technical efficiency. Therefore, this study also helps to identify and compare the efficiency level of Nepalese improve and others (Indian and local) potato varieties.

Irrigation is one of the important factors to increase potato productivity. A regular water supply is necessary to gain a higher potato yield (lerna et al. 2011; Levy et al. 2013). However, drought has an adverse effect on potato growth and productivity (Levy et al. 2013). Panta et al. (2019) in Dadeldhura 
district of Nepal found that only $13.3 \%$ of the potato land had irrigation facilities.. Likewise, a study conducted in the Terai region of Nepal found that lack of proper irrigation facilities was one of the important problems in potato farming (Subedi et al. 2019). In Nepal, technical efficiency of potato cultivation in irrigated and rainfed conditions is lacking. This study identified the efficiency level of both irrigated and rainfed potato farmers.

The primary objective of this study is to estimate the impact of Nepalese improved varieties and irrigation on the technical efficiency of potato production. Secondly, the paper also provides a detailed analysis of technical efficiency of potato production and yield gap due to technical inefficiency in Nepal.Thus, this study is important to policymakers as the information can be used to identify major interventions areas to improve productivity. Furthermore, identification and implementation of appropriate management practices to increase efficiency will result in increasing potato productivity among the potato farmers in Nepal.

\section{Research Methodology}

The data for this study was obtained from a survey of potato farmers from the Terai region of Nepal, which covered three districts: Jhapa from eastern, Bara from central, and Kailali from western Terai of the country. The Multistage random sampling procedure was employed for the selection of respondents. In the first stage, three districts were selected based on the highest potato area from each three regions. After that, three pockets in each district were selected based on potato area and variety usedto capture the variations within the districts after the consultation withAgriculture Knowledge Centre and agricultural officials of the local government. Lastly, 100 households from each district were selected using proportionate random sampling from each pocket. Therefore, a total of 300 households were selected for the study. A questionnaire was restructure according to the feedback from the pretesting. The households' survey was conducted from February to April 2018. The interview schedule questionnaire captured data on the amount of potato production and production-related socioeconomic variables. Information was collected on input-output variables such as labor hours, farm size, fertilizer dose, tillage hours, and seed quantity.Socio-demographic factors such as age, education, access to credit, training received, household size, migration status, variety types, and irrigation application. One focus group discussion was conducted in each pocket. The Collected information from three districts was entered in excel and data analysis was conducted by using software Stata (version 16.1). The research area is delineated in picture 1.

\section{Methods Of Data Analysis \\ 3.1 Descriptive statistics}

Descriptive statistics was used to analyze the survey data using measures of dispersion such as percentage, frequency, and measures of central tendency such as mean, and standard deviation

\subsection{Econometric model}


The focus of this study was to find out the impact of improved varieties on the technical efficiency of potato farmers across the Terai region of Nepal.There are two methods to determine technical efficiency as data envelopment analysis (DEA) and stochastic frontier method. The former is a nonparametric approachthat developed out of mathematical programming techniques while the later is a parametric approach that estimatestechnical efficiency within a stochastic production function model (Chakraborty et al. 2002; Coelli et al. 2005). The parametricapproach considersthe production functional form from a priori estimation of the data, while the non-parametric approach uses the data to determine the functional form. The major limitation of the non-parametric approach is that it assumes no sampling error and attributes all deviation from the production frontier to inefficiency (Diagne et al. 2013). In this study, thestochastic frontier analysis was used in preference to the DEA.

\subsubsection{Stochastic production frontier model}

The stochastic frontier regression model is a parametric analysis that has been commonly used to estimate technical inefficiency. The stochastic production function frontier shows the most efficient use of inputs to produce the maximum output. This study uses the method of estimating a stochastic frontier production function proposed by Aigner et al. (1977), and Meeusen and Van Den Broeck (1977). Kumbhakar et al. (1991) extended the stochastic frontier methodology by openly introducing the determinants of technical efficiency into the model. The stochastic frontier production function differs from the traditional production function in that it consists of two error terms. The first error term accounts for technical efficiency and the second for factors such as measurement error in the output variable, the weather, and the combined effects of unobserved inputs. It is a homogeneous function that provides a scale factor enabling one to measure the return to scale and to interpret the elasticity coefficients with relative ease. It is also relatively easy to estimate because in the logarithmic form; it is linear and parsimonious (Beattie and Taylor 1985).

\subsubsection{One-step Stochastic Production Frontier}

In previous,two-step procedure was commonly used in the estimation of the stochastic production frontier. This approach estimates the observation-specific inefficiency measure in the first step, and then estimates the effect of the explanatory variables on the inefficiency measures in the second step. The two-step estimation procedure recognized as biased because the model estimated in the first step is misspecified (Battese and Coelli 1995). Furthermore,Wang and Schmidt (2002) explained that if X (Input variables) and Z (Inefficiency variables) are correlated then the first step of the two-step procedure is biassed. Even they are uncorrelated, ignoring the dependence of the inefficiency on Z will cause the firststep technical efficiency index to be undispersed, so that the results of second step estimations are likely to be biased downward.Due to the unsatisfactory statistical properties of the two-step estimation, the better approach of incorporating exogenous influence on efficiency is the one-step procedure. Kumbhakar et al. (1991) and Reifschneider and Stevenson (1991) proposed one-step stochastic frontier in which the inefficiency effects (ui)expressed as an explicit function of the vector of firm-specific variables and a 
random error.Therefore, in this study, allthe parameters of the stochastic frontier modeland inefficiency function were estimated together with a singlemaximum likelihood estimation (MLE) procedure.

\subsubsection{Functional forms determination}

Several functional forms have been developed to measure the relationship between input and output. The most common functional forms are Cobb-Douglas andtranscendental logarithmic (translog) function.The Cobb-Douglas has been widely used in many empirical studies particularly thoserelated to developing countries for farm efficiency analysis (Bravo-Ureta and Pinheiro 1997). Cobb-Douglas specification provides an adequate representation of agricultural production technology. In this study, we use an empirical Cobb-Douglas frontier production function model with double log form can be expressed as:

$\operatorname{Ln}($ yield $)=\beta_{0}+\beta_{1} \ln ($ Total labour in hours $)+\beta_{2} \ln ($ Inorganic fertilizer $)+\beta_{3} \ln ($ Ploughing hours $)+\beta_{4} \ln ($ Total seed $)+\beta_{5} \ln ($ Area cultivation $)+€ i\left(V_{i}-U_{i}\right)$

Where, $L n$ is the natural logarithm, the dependent variable yield is the potato production per hectare $(\mathrm{Kg} / \mathrm{ha}), \beta_{0}-\beta_{5}$ arethe parameters to be estimated. The inputs variable are totallabour hours required per hectare, inorganic fertilizer is the amount of Nitrogenous, Phosphatic, Potassic and other micronutrients per hectare $(\mathrm{Kg} / \mathrm{ha})$, ploughing constitutes total tillage hours required for one hectare of land, total seed is the potato seed rate per hectare ( $\mathrm{kg} / \mathrm{ha})$, area cultivation is the area under potato cultivation (ha), $€ \mathrm{i}$ is the error term, equal to $\left(V_{i}-U_{i}\right), V_{i}$ is a two-sided random error component beyond the control of the farmer and $\mathrm{U}_{\mathrm{i}} \mathrm{is}$ a one-sided inefficiency component. In this study, the half-normal distribution is assumed for the asymmetric technical inefficiency parameter.

\subsubsection{Estimation of technical efficiency}

The farm specific technical efficiency $\left(T E_{i}\right)$ of the ith sample farmer was estimated by using the expectation of $\mathrm{U}_{i}$ conditional on the random variable $€ \mathrm{i}$

$\mathrm{TE}_{\mathrm{i}}=\operatorname{Exp}\left(-\mathrm{U}_{\mathrm{i}}\right)$

$=Y_{i} / f\left(X_{i} ß\right) \exp V_{i}$

$=Y_{i} / Y^{*}$

Where, $Y_{i}=$ Observed output

$Y^{*}=$ Frontier output

If $Y_{i}=Y^{*}$

Then, $\mathrm{TE}_{\mathrm{i}}=1$ i.e. $100 \%$ efficient 


\subsubsection{Technical inefficiency model}

After obtaining technical efficiency, we have estimated socioeconomic determinants of technical inefficiency.

Technical inefficiency determinants are as follows;

$U_{i}=\beta_{0}+\beta_{1 i}($ Seed $)+\beta_{2 i}($ Training $)+\beta_{3 i}($ Migration $)+\beta_{4 i}($ Education $)+\beta_{5 i}($ Irrigation $)+$

$\beta_{6 i}($ Variety types $)+W_{i}$

Where, $U_{i}$ is technical inefficiency. The subscript $i$, indicates the ith household in the sample $(i=$ $1, \ldots \ldots . ., 300) . \beta_{0}, \ldots \ldots . . . . \beta_{6}$ are the parameters to be estimated. Seed represents the source of seed for potato farming 1 if it is formal, 0 otherwise; training represents training related to potato farming 1 if participated in training activities in last 5 years, 0 otherwise; migration represents any of the household members go to other countries 1 if they go to abroad, 0 otherwise; education represents years of schooling of the household head. Likewise, 1 represents if farmers applied irrigation in potato farming, 0 otherwise and variety represents potato seed varieties 1 if the household used Nepalese improved variety seed, 0 if they adopted Indian and local seed varieties.

\section{Results}

\subsection{Summary statistics}

The variables used in this study are presented in Table 1. For the stochastic production function variables, the average total potato output was 12.75 metric tons per hectare while the lowest was 1.2 metric tons per ha. The highest total potato production was 30 metric tons per ha. The productivity is lower than the national average productivity which was $14.76 \mathrm{mt} / \mathrm{ha}$ in 2018 (MoALD 2019). The average potato cultivated area recorded was 0.15 ha with the lowest area cultivated being 0.008 ha while the largest cultivated area was 1.33 ha. Farmers used an average of 970 hours of labour to produce the potatoper hectare, but there was a wide variation from 306 to 2782 hours. Most of the farmers performed potato cultivation activities manually. The average amount of seeds used were about $1690 \mathrm{~kg}$ per ha. It is lower than the recommended dose, which is $2000 \mathrm{~kg}$ per ha. The average quantity of inorganic fertilizers (DAP, Urea \& Potash) used was about $374 \mathrm{~kg}$ per ha. Among them, farmers applied DAP $119 \mathrm{~kg}$, Urea $140 \mathrm{~kg}$ \& Potash $100 \mathrm{~kg}$ in one hectare of land. The recommended dose is $220 \mathrm{~kg} \mathrm{DAP}, 140 \mathrm{~kg}$ Urea \& $100 \mathrm{~kg}$ Potash per hectare. Farmers were applying less quantity of DAP and Potash than recommendation dose. Almost all of the farmers performed tillage operation by a tractor. Farmers used an average of 13 hours for tillage operation to produce potatoes in one hectare. 
Table 1

Descriptive statistics of the variables used in the model $(\mathrm{N}=300)$

\begin{tabular}{|lllll|}
\hline Variables I & Mean & Std. Dev. & Min & Max \\
\hline Total potato productivity (kg/ha) & 12753 & 5469 & 1200 & 30000 \\
\hline Total potato area (Hectare) & 0.15 & 0.18 & 0.008 & 1.33 \\
\hline Total labour (hours) & 970 & 370 & 306 & 2782 \\
\hline Seed quantity (kg/ha) & 1690 & 656 & 450 & 6000 \\
\hline Tillage hours (hour/ha) & 13.06 & 6.47 & 2 & 33.33 \\
\hline Total inorganic fertilizer (kg/ha) & 374.28 & 272.54 & 0 & 1875 \\
\hline Seed source formal (Yes \%) & 42 & 0.49 & 0 & 1 \\
\hline Training (Yes \%) & 19 & .39 & 0 & 1 \\
\hline Migration (Yes \%) & 21.33 & 0.41 & 0 & 1 \\
\hline Education of household head (Years) & 6.08 & 4.22 & 0 & 16 \\
\hline Irrigation used (Yes \%) & 82 & 0.39 & 0 & 1 \\
\hline Nepalese improved potato varieties (Yes\%) & 47.33 & 0.50 & 0 & 1 \\
\hline Source: Field Survey, 2018 & & & & \\
\hline
\end{tabular}

To determine factors related to inefficiency, socioeconomic variables were incorporated into the stochastic frontier model. About $42 \%$ of farmers obtained seed from a formal source. Formal sources include government farm, cooperatives, and agrovets while informal source consists of own saving and seed from neighbours and relatives. In terms of training, only $19 \%$ of farmers received potato related training while about $21 \%$ of household members were migrated to other countries. The average education was 6 years of schooling.Furthermore, about $82 \%$ of farmers used irrigation through pumps and canal irrigation in potato farming. Lastly, in terms of variety, about $47 \%$ of farmers used Nepalese improved (NARC released and registered) varieties, while the other farmers used Indian and local varieties. The major Nepalese varieties include Janakdev, Cardinal and Khumal Red. Indian varieties were Arun Gold, C 40 \& Kanpurwhereas farmers cultivated Tharu Aalu as a local variety.

\subsection{Hypothesis testing}

Before proceeding to the empirical analyses of technical efficiency and its determinants, a generalized likelihood ratio (LR) test was employed to determine which model is better. We used a LR test based on log-likelihood values of restricted and the unrestricted model. In this study, the LR test was performed to test three null hypotheses (Table 2). The first null hypothesis tested was the test for the existence of the inefficiency component of the composed error term. The null hypothesis was no inefficiency problem 
exists in potato farmers. This null hypothesis was rejected at one degree of freedom and $1 \%$ level of significance because LR-value (124.72) is greater than the critical value (5.41) (Annex 3).

The second null hypothesis tested was a test for appropriate functional form; Cobb-Douglas versus Translog production functional form. The calculated LR test value is equal to -100.09 and the critical value of chi2 at 15 degrees of freedom at $5 \%$ level of significance is 29.92, which is higher than the critical value (Annex 4). This implies that the Cobb-Douglas functional form was preferred to estimate the technical efficiency of the potato farmers. The third null hypothesis evaluated between half-normal and truncated normal distribution (Annex 4). The null hypothesis is accepted, therefore, we used half-normal distribution in the stochastic production frontier model.

Table 2

Summary of the test of hypothesis

\begin{tabular}{|llllll|}
\hline S.N & Null hypothesis & $\begin{array}{l}\text { Degree } \\
\text { of } \\
\text { freedom }\end{array}$ & $\begin{array}{l}\text { LR- } \\
\text { value }\end{array}$ & $\begin{array}{l}\mathbf{X}^{2} \\
\text { value }\end{array}$ & Decision \\
\hline 1. $\quad \mathrm{H}_{0}=$ Technical inefficiency not exist & 1 & 124.72 & 5.41 & Reject \\
& $\mathrm{H}_{1}=$ Presence of technical inefficiency & & & \\
\hline 2. $\quad \begin{array}{l}\mathrm{H}_{0}=\text { Appropriate production functional form is } \\
\text { Cobb-Douglas }\end{array}$ & 15 & -100.09 & 29.92 & Accept \\
& $\begin{array}{l}\mathrm{H}_{1}=\text { Appropriate production functional form is } \\
\text { Translog }\end{array}$ & & & & \\
\hline 3. $\quad \begin{array}{l}\mathrm{H}_{0}=\text { The inefficiency effect follows a half normal } \\
\text { distribution }\end{array}$ & 2 & 4.57 & 8.27 & Accept \\
$\begin{array}{l}\mathrm{H}_{1}=\text { The inefficiency effect follows a truncated } \\
\text { normal distribution }\end{array}$ & & & & \\
\hline
\end{tabular}

\subsection{Empirical results}

Before the estimation of stochastic frontier production function model, explanatory variables and inefficiency variables selected for estimation were checked for the multicollinearity problem using variance Inflation factor (VIF) (Annex 1\&2). The value of VIF above 10 is considered as serious multicollinearity (Gujarati 2006), but in our result none of the variables VIF value exceed 2;average VIF value foundin case of explanatory variableswere 1.08 and 1.07 for inefficiency variables(Appendix 1 and 2). 
Table 3

Input elasticity and socio-economic determinants of inefficiency

\begin{tabular}{|c|c|c|c|}
\hline Variable & Coefficient & Standard error & p-value \\
\hline Log potato area (ha) & $0.106^{* \star *}$ & 0.026 & 0.000 \\
\hline Log seed $(\mathrm{Kg} / \mathrm{ha})$ & $0.503^{\star \star \star}$ & 0.070 & 0.000 \\
\hline Log labor (hours/ha) & $0.162^{\star \star \star}$ & 0.064 & 0.012 \\
\hline Log ploughing (hours/ha) & 0.048 & 0.041 & 0.248 \\
\hline Log total inorganic fertilizer $(\mathrm{Kg} / \mathrm{ha})$ & -0.008 & 0.009 & 0.407 \\
\hline Constant & $5.101^{\star \star \star}$ & 0.669 & 0.000 \\
\hline \multicolumn{4}{|l|}{ Inefficiency component } \\
\hline Seed source formal (Yes \%) & -0.231 & 0.237 & 0.330 \\
\hline Training (Yes \%) & 0.273 & 0.290 & 0.348 \\
\hline Migration (Yes \%) & -0.233 & 0.284 & 0.413 \\
\hline Education of household head (Years) & -0.028 & 0.027 & 0.291 \\
\hline Irrigation used (Yes \%) & $-1.043^{\star \star \star}$ & 0.303 & 0.001 \\
\hline Nepalese improved potato varieties (Yes\%) & $-0.791^{\star \star \star}$ & 0.272 & 0.004 \\
\hline Constant & $0.046^{\star \star \star}$ & 0.298 & 0.877 \\
\hline \multicolumn{4}{|l|}{ Other statistics } \\
\hline sigma_u & 0.501 & & \\
\hline sigma_v & 0.258 & & \\
\hline Gamma $(\gamma)$ & 0.79 & & \\
\hline Lambda & 1.183 & & \\
\hline Log likelihood & -142.88 & & \\
\hline Number of observations & 300 & & \\
\hline Wald $\operatorname{chi}^{2}(6)$ & 79.54 & & \\
\hline Note: ${ }^{*} P<0.1, * \star P<0.05, * \star * P<0.01$ & & & \\
\hline
\end{tabular}

A Cobb-Douglas production function was estimated using half normal stochastic production methods. All input variables and dependent variables are log-transformed, the coefficient represents elasticity. The value of gamma was 0.79 , which is the ratio of the variance of the inefficiency component to the total 
error term. It indicates that about $79 \%$ variation in the output of potato farmers was due to technical efficiencies. Additionally, the value sum of the estimated parameters associated with all the inputs is 0.82 which indicates decreasing return to scale. This implies that a $1 \%$ increase in these all production input variables leads to $0.81 \%$ increase in potato production.

We found that potato area; seed quantity and labour use are significant and have a positive and significant effect on potato production. The coefficient of potato farm size is significant and positive at the $1 \%$ level of significance. The result implies that a $1 \%$ increase in potato area increases the value of potato output by $0.13 \%$.Seed quantity is significant at $1 \%$ level of significance. The findings indicate that $1 \%$ increase in seed quantity increases the potato production by $0.52 \%$. Similarly, labour quantity is positive and significant at the $10 \%$ level of significance, indicating that a $1 \%$ increase in the labour quantity increases the potato output by $0.17 \%$.

The inefficiency factors presented in Table 3 relate to the farmers' socio-economic characters. The variables include seed source, training received related to potato farming, migration, education of household head, use of Nepalese improved potato varieties and availability of irrigation.The dummy variable use of Nepalese improved potato varieties had a negative effect on technical inefficiency and significant at $1 \%$ level of significance. Likewise, the coefficient of irrigation availability had a negativeand significant at $1 \%$ level of significance. This means that when other factors are held constant, farmers who irrigated at least one time to potato farming are more technically efficient than others who didn't apply irrigation.

\subsection{Level of Technical Efficiency of Potato Farmers}

Table 4 shows the summary and distribution of technical efficiency of potato farmers in the Terai region of Nepal. We found a mean technical efficiency score of about 0.69 with a standard deviation of 0.16 . The TE scores for potato farmers in the sample ranged from 0.11 to 0.93 . The average technical efficiency for surveyed farmers was $69 \%$. A higher percentage of farmers $(57 \%)$ have a TE value of more than $70 \%$. Nearly, about a quarter of the farmers hada TE value of less than $60 \%$. 
Table 4

Distribution of technical efficiency of potato farmers in the Terai region of Nepal

\begin{tabular}{|lll|}
\hline Efficiency level & Frequency & Percent (\%) \\
\hline Less than 0.5 & 36 & 12.00 \\
$0.51-0.6$ & 38 & 12.66 \\
$0.61-0.7$ & 54 & 18.00 \\
$0.71-0.8$ & 84 & 28.00 \\
$0.81-0.9$ & 84 & 28.00 \\
$0.91-1.0$ & 4 & 1.33 \\
\hline Total & 300 & 100 \\
\hline Mean & 0.69 & \\
\hline Standard deviation & 0.16 & \\
\hline Minimum & 0.11 & \\
\hline Maximum & 0.93 & \\
\hline
\end{tabular}

Table 5 shows the distribution of technical efficiency of potato farmers by variety types and irrigation conditions. Farmers were cultivating three types of varieties i.e. Nepalese improved (NARC released and registered), Indian and local. The result indicates that Nepalese improved varieties adopter farmers are more efficient $(73 \%)$ than Indian $(66 \%)$ and local $(59 \%)$ potato varieties. Likewise, in terms of irrigation condition, the technical efficiency of irrigated potato farmers was 71 per cent while in rainfed conditionswas 61 percent.

Table 5

Distribution of technical efficiency of potato farmers in Nepal, by variety type and Irrigation condition

\begin{tabular}{|lllll|}
\hline Variables & Mean & Standard deviation & Minimum & Maximum \\
\hline Variety type & & & & \\
\hline Nepalese Improved & 0.73 & 0.13 & 0.31 & 0.93 \\
\hline Indian & 0.66 & 0.16 & 0.11 & 0.91 \\
Local & 0.59 & 0.17 & 0.23 & 0.82 \\
\hline Irrigation condition & & & & \\
Irrigated & 0.71 & 0.13 & 0.30 & 0.93 \\
Rainfed & 0.61 & 0.21 & 0.11 & 0.89 \\
\hline
\end{tabular}




\subsection{Estimates of potato yield gap due to inefficiency}

Yield gap is defined as the difference between technically full efficient production and actual production in farmers' fields. Therefore, the yield gap is the amount which represents a lower yield due to technical inefficiency. From the stochastic model, TE of the ith household is estimated to be:

$T E_{i}=Y_{i} / Y_{i}^{*}$

$\mathrm{Y}_{\mathrm{i}}^{*}=\mathrm{Y}_{\mathrm{i}} / \mathrm{TE} \mathrm{E}_{\mathrm{i}}$

WhereTE $E_{i}$ is the technical efficiency of the ith sample household in potato production;

$\mathrm{Y}_{\mathrm{i}}=$ Actual/observed yield of the ith sample household in potato production

$Y_{i}^{*}=$ Frontier/ potential output of the ith sample household in potato production

Based on the above equation, we estimated the potential yield of potato for each sample household in potato production. The result is presented in Table 6 . The computed mean potential yield was 17755 $\mathrm{kg} / \mathrm{ha}$. It was noticed that the mean yield gap was $5,002 \mathrm{~kg} / \mathrm{ha}$ at $69 \%$ mean technical efficiency with actual average output and the potential outputs were $12,753 \mathrm{~kg} / \mathrm{ha}$ and $17,755 \mathrm{~kg} / \mathrm{ha}$ respectively. This indicates that surveyed households were producing $5,002 \mathrm{~kg} / \mathrm{ha}$ lower potato production than their potential yield.

Table 6

Potato yield gap due to technical inefficiency

\begin{tabular}{|lllll|}
\hline Variable & Mean & Min & Max & Std. Dev. \\
\hline Actual yield (Kg/ha) & 12753 & 1200 & 30000 & 5469 \\
\hline TE estimates & 0.694 & 0.108 & 0.927 & 0.155 \\
\hline Potential/frontier yield (Kg/ha) & 17755 & 7150 & 34276 & 4948 \\
\hline Yield gap/loss (Kg/ha) & 5002 & 1896 & 17262 & 2147 \\
\hline
\end{tabular}

\section{Discussion}

The result found production variables such as farm size, the seed used and labour used contributed positively towards technical efficiency, whereas in the efficiency model, variety type and irrigation are major factors that determine technical efficiency.

The stochastic frontier model estimated potato land area has a higher efficiency level implies that potato productivity could be increased by further expanding the cultivated area or shifting other lands for potato farming. Larger farmers have much greater access to public services, credit and other inputs (Sharif and Dar 1996) wheareas, farmers with small land size cultivating more intensively and inadequate allocation 
of inputs (Khanal et al. 2018). Prasanna and Lakmali (2016) and Tiruneh et. al. (2017) also found a positive association between potato farm size and technical efficiency. Another significant variable is seed rate that farmers are using less seed rate than recommended. The higher rate of seed quantity increases the plant population and increases yield (Ahmad et. al. 2006). A study conducted by Bajracharya \& Sapkota (2017) also reported that farmers were unaware of the recommended rate of seed rate and using a lower rate of seed in Baglung district of Nepal. However, the result is contradicted with Wassihun et al. (2019), they mentioned that seed rate with higher than recommended may result in low potato production due to high competition of nutrients. Likewise, Potato farming is the labour-intensive and farmers rely heavily on manual labour. The higher number of labour is required for better weeding, fertilizer and pesticide application. Similarly, more labouris also required for land preparation, planting, and harvesting processes. Therefore, the higher number of labour used households not only performed their cultural activities very well but also increased their level of technical efficiency. The result is consistent with Dubeet. al. (2018) in Ethiopia found that amount of seed, area of the plot and labour were positive and significant input variables in potato production.

Farmers who adopted NARC released and registered potato varieties were more efficient than farmers who adopted Indian and local potato varieties. Moreover, the way potato farmers increase their productivity depends on the type of varieties they used for potato cultivation. In Nepal, lack of improved quality seed was the most important problem in potato production (Subedi et al. 2019). At the same time, farmers are unaware of the quality seed variety that's why farmers used ware potato as a seed. Most of the Indian and local varieties adopting farmers used ware potato as a seed because those varieties don't have any formal seed chain. However, NARC has produced Nepalese improved varieties of pre-basic seed each year which help to maintain the seed chain. Wassihum et al. (2019) also found that potato farming with improved varieties was more efficient compared to using local varieties. Furthermore, similar findings that the use of improved varieties and technical efficiency were positively correlated (Jwanya et.al. 2014; Deressa et al. 2017). Our finding also suggested that about 7 per cent and 16 per cent technical efficiency of potato farmers can be increased by replacing Indian and local varieties respectively through Nepalese varieties. Likewise, potato farming with irrigation is more efficient than rainfed farming. In Nepal, potatoes arebeing cultivated in both irrigated and rainfed conditions. Irrigation has an important role as they are very sensitive to water stress during tuber initiation and tuber bulking stages, which have an adverse effect on potato productivity (Foti et al., 1995; lerna and Mauromicale, 2012). Mardani and Salarpour (2015) stated that irrigation improvement along with a proper application of fertilizers, pesticides, and machinery can have a significant role in the efficiency of potato production. Furthermore, the efficiency of potato farmers can be increased by 10 per cent with the provision of irrigation by converting rainfed to irrigate potato farms.

Lastly, there is still 31 per cent possibility to increase the level of technical efficiency of potato farmers with existing technologies and resources. The findings are consistent with the result obtained by Tiruneh et.al. (2017), they found that the technical efficiency of potato farmers were $68 \%$ in irrigated condition. 


\section{Conclusion}

This paper estimates the impact of variety type and irrigation on the efficiency of potato production. Moreover, it also determines the technical efficiency level of potato farmers and its determinants in Nepal. The empirical analysis was carried out by employing half normal stochastic frontier analysis. Results showed that among the five main factors of production (land, labour, fertilizer, tillage hours and seeds) used, potato area, labour and seed were the major factors associated with potato production. The significant determinants of technical inefficiency variables include the use of Nepalese improved varieties and irrigation availability. Use of NARC released improved varietieswas also positively significant to the technical efficiency of potato farmers. Farmers who adopted NARC released potato varieties (Janakdev, Cardinal, Khumal Red, etc.) havea higher level of technical efficiency than those farmers who adopted Indian (Arun Gold, Kanpure, C-40) and local varieties (Tharualu). Farmers who applied irrigation in potato farming were more technically efficient than others. The finding also indicates that Nepalese improved varieties adopted farms are more technically efficient than Indian and local varieties user farms.

The technical efficiency of potato farmers could be increased by $31 \%$ onaverage through better use of labour, seed and land. For better improvement of efficiency factors, farmers should use Nepalese improved varieties instead of Indian and local potato varieties and there should be an expansion of irrigation facilities for better potato production in the Terai region of Nepal.

\section{Declarations}

\section{Ethics approval and consent to participate}

The study obtained permission from participants to involve in the study and received an ethical clearance

\section{Consent for publication}

It is not applicable for this article

\section{Authors' contribution}

SPA designed and collected the data and drafted paper. YNG, KPT and SG edited and provided feedback to improve the paper. All authors read and approved the final manuscript.

\section{Funding}

The research was fiunded by Nepal Agricultural Research Council.

\section{Availability of data and materials}

The datasets used in this article are available from the corresponding author on request.

\section{Competing interests}


The authors declare that they have no competing interests.

\section{Acknowledgement}

We would like to thank all colleagues who helped to collect the data during the survey. We are grateful to the farmers in Jhapa, Bara and Kailali district of Nepal who gave their valuable information and time to complete this research

\section{References}

1. Adhikari CB, Bjorndal T (2012) Analyses of technical efficiency using SDF and DEA models: evidence from Nepalese agriculture. Applied Economics, 44 (25):3297-3308. ISSN 0003-6846

2. Ahmad B, Abedullah BK (2006) Technical efficiency and its determinants in potato production, evidence from Punjab, Pakistan. Lahore J Econ 11(2):1-22

3. Aigner D, Lovell CAA, Schmidt P (1977) Formulation and estimation of stochastic frontier production function models. Journal of Economics 6 (1):21-37

4. Amara N, Traorr N, Landry R, Romain R (1999) Technical efficiency and farmers' attitudes toward technological innovation: The case of the potato farmers in Quebec. Canadian Journal of Agricultural Economics 47:31-43

5. Bajracharya M, Sapkota M (2017) Profitability and productivity of potato (Solanumtuberosum) in Baglung district, Nepal. Agriculture \& Food Security 6(47): 1-8

6. Barasa AW, Odwori PO, Barasa J, Ochieng S (2019) Technical Efficiency and Its Determinants on IrishPotato Farming among Small Holder Farmers inTrans-Nzoia County-Kenya. International Journal of Research and Innovation in Social Science 5(3):235-238

7. Battese GE, Coelli TJ (1995) A Model for Technical Inefficiency Effects in a Stochastic Frontier Production Function for Panel Data. Empirical Economics 20(2):325-332

8. Beattie BR, Taylor CR (1985) The Economics of Production. Montana State University, John Wiley \& Sons, New York, USA.

9. Bravo-Ureta BE, Pinheiro AE (1997) Technical, economic and allocative efficiency in peasant farming: evidence from theDominican Republic Dev Econ 34:48-67

10. Bhattarai B, Beilin R, Ford R (2015) Gender, agrobiodiversity, andclimate change: a study of adaptation practices in the Nepal Himalayas. World Dev 70:122-132

11. Chakraborty C, Mishra SK, Johnson PN (2002) Cotton farmer's technical efficiency: Stochastic and nonstochastic production function approaches. Agric. Resour. Econ. Rev 31: 211-220

12. Deressa B, Garoma D, Sekhara Reddy OC, Alemu B (2017) Analysis of technical efficiency of potato (Solanumtuberosum)production: in the case of Welmera Districts, Oromia Regional State, Ethiopia. Int J Basic Appl Sci 7(1):43-56

13. Diagne M, Demont M, Seck P, Diaw A (2013) Self-sufficiency policy andirrigated rice productivity in the Senegal River Valley. Food Secur 5 (1) 55 doi:10.1007/s12571-012-0229-5 
14. Dube AK, Ozkan B, Ayele A, Idahe D, Aliye A (2018) Technical efficiency and profitability of potato production by smallholder farmers: The case of Dinsho District, Bale Zone of Ethiopia. Journal of Development and Agricultural Economics 10(7): 225-235

15. Farrel M (1957) The measurement of production efficiency. Journal of the Royal Statistical Society 120(3):253-290

16. Food and Agriculture Organization of the United Nations (2018) FAOSTAT statistical database. [Rome] :FAO

17. Foti $S$, Mauromicale $G$, lerna $A$ (1995) Influence of irrigation regimes on growth and yield of potato cv. Spunta. Potato Research 38:307-318

18. Gairhe S, Gauchan D, Timsina K (2017) Adoption of improved potato varieties in Nepal. Journal of Nepal Agriculture Research Council 31: 38-44 doi:10.3126/jnarc.v3i1.17274

19. Galabada JK, Warnakulasooriya HU, Karunagoda KS, Perera THCS (2014) Level of protection and competitiveness of potato sector, Sri Lanka. Annals of the Sri Lanka Department of Agriculture 16:169-181

20. Gujarati DN (2006) Basic econometrics, 4th edn. Tata Mc Graw-Hill, New Delhi

21. lerna A, Mauromicale G (2012) Tuber yield and irrigation water productivity in early potatoes as affected by irrigation regime. Agric. Water Manage 115:276-284

22. Ierna A, Pandino G, Lombardo S, Mauromicale G (2011) Tuber yield, water and fertilizer productivity in early potato as affected by a combination of irrigation and fertilization. Agric. Water Manage 101:35-41.

23. Jwanya BA, Dawang NC, Mashat IM, Gojing BS (2014) Technical efficiency of rain-fed Irish potato farmers in Plateau State,Nigeria: a stochastic frontier approach. Developing Country Studies 22(4):34-39

24. Kafle B, Shah P (2012) Adoption of improved potato varieties in Nepal: A case of Bara district. J Agri Sci,7(1): 14-22

25. Khanal U, Wilson C, Shankar S, Hoang VN, Lee B (2018) Farm performance analysis: Technical efficiencies and technology gaps of Nepalese farmers in different agro-ecological regions. Land Use Policy 76: 645-653 https://doi.org/10.1016/j.landusepol.2018.02.045

26. Kumbhakar, SC, Ghosh S, McGuckin J (1991) A generalized production frontierapproach for estimating determinants of inefficiency in U.S. Dairy Farms. Journal of Business \& Economics Statistics 9(3): 279-286

27. Levy D, Coleman WK, Veilleux RE (2013) Adaptation of Potato to Water Shortage: Irrigation Management and Enhancement of Tolerance to Drought and Salinity. American Journal of Potato Research 90:186-206 Doi: 10.1007/s12230-012-9291-y

28. Mardani M, Salarpour M (2015) Measuring technical efficiency of potato production in Iran using robust data envelopment analysis. Information Processing in Agriculture 2: 6-14 
29. MoALD.(2019) Statistical Information on Nepalese Agriculture. Ministry of Agricultural and Livestock Development. Monitoring, evaluation and statistics division, Singhdurbar, Kathmandu.

30. Meeusen W, Broeck JVD (1977) Efficiency estimation from Cobb-Douglasproduction functions with composed error. International Economic Review 18 (2):435-444

31. Panta S, Sigdel UP Awasthi GD (2019) Adoption of recommended production practices of cardinal variety of potato among potato growing farmers in Dadeldhura. ACTA Scientific Agriculture 3 (2): $144-148$

32. Prasanna R, Lakmali N (2016) Estimating technical efficiency among smallholder potato producers in Welimada, Srilanka. Srilanka Journal of Economic Research 4(1): 59-74

33. Reifschneider D, Stevenson R (1991) Systematic departures from the frontier: aframework for the analysis of firm inefficiency. International Economic Review 32 (3):715-723

34. Sharif N R, Dar A (1996) An empirical study of the patterns and sources of technical efficiency in traditional and HYV rice cultivation in Bangladesh. Journal of Development Studies 32: 612-629.

35. Shrestha RB, Huang WC, Ghimire R (2014) Production Efficiency of Smallholder Vegetable Farms in Ilam District, Eastern Hill, Nepal.American- Eurasian Journal of Agriculture \& Environment Science 14(2): $150-154$

36. Subedi S, Ghimire YN, Gautam S, Poudel HK, Shrestha J (2019). Economics of potato (Solanumtuberosum L.) production in Terai region of Nepal. Archives of Agriculture and Environmental Science 4(1):57-62 https://dx.doi.org/10.26832/24566632.2019.040109

37. Timsina KP, Gairhe S, Ghimire YN, Poudel HK, Devkota D, Subedi S, Adhikari S.P. (2019) Returns to Potato Research Investment in Nepal. Journal of Agriculture and Natural Resources 2(1):1-13 DOI: https://doi.org/10.3126/janr.v2i1.26002

38. Tiruneh GW, Chindi A, Woldegiorgis G (2017) Technical efficiency determinants of potato production: A study of rain-fed and irrigated smallholder farmers in Welmera district, Oromia, Ethiopia. Journal of Develoment and Agricultural Economics. 9(8): 271-273. DOI: 10.5897/JDAE2016.0794

39. Tufa AH, Gielen-Meuwissen MPM, Lommen WJM, Tsegaye A, Struik PC, Lansink AGJM (2015) Leastcost seed potato production in Ethiopia. Potato Research

40. Wan HJ, Schmidt P (2002) One-step and two-step estimation of the effects ofexogenous variables on technical efficiency levels. J. Prod. Anal. 18 (2):129-144

41. Wassihun AN, Koye TD, Koye AD (2019) Analysis of technical efficiency of potato (Solanumtuberosum L.) production in Chilga District, Amhara National Regional State, Ethiopia. Economic Structures 8(34):1-18 https://doi.org/10.1186/s40008-019-0166-y

42. Wilson P, Hadley D, Ramsden S, Kaltsas I (1998) Measuring and Explaining Technical Efficiency in UK Potato Production. Journal of Agricultural Economics 49(3):294 -305

43. Coelli TJ, Rao DSP, O’Donnell CJ, Battese GE (2005) Introduction to efficiency and productivity analysis, 2nd edn. Springer, Heidelberg 


\section{Annex}

Annex 1: VIF of the explanatory variables for stochastic production function analysis

\begin{tabular}{|lll|}
\hline Variable & VIF & $1 /$ VIF \\
\hline Total labor hour & 1.10 & 0.911615 \\
\hline Ploughing hour & 1.09 & 0.913260 \\
\hline Total potato area & 1.08 & 0.928167 \\
\hline Total chemical fertilizer & 1.07 & 0.935075 \\
\hline Total seed quantity & 1.05 & 0.953557 \\
\hline Mean VIF & 1.08 & \\
\hline
\end{tabular}

Annex 2:VIF for inefficiency variables in technical inefficiency model

\begin{tabular}{|lll|}
\hline Variable & VIF & $1 /$ VIF \\
\hline Education & 1.11 & 0.900058 \\
\hline Potato variety & 1.08 & 0.925480 \\
\hline Training & 1.06 & 0.944040 \\
\hline Seed source & 1.06 & 0.946307 \\
\hline Migration & 1.05 & 0.951140 \\
\hline irrigation & 1.03 & 0.967524 \\
\hline Mean VIF & 1.07 & \\
\hline
\end{tabular}

\section{Annex 3: Test for technical inefficiency}

displayll_ols

-221.45927 (Log-likelihood value of ordinary least square model)

displayll_cdhn

-159.0981 (Log-likelihood value of half normal model)

display -2*(II_ols - II_cdhn)/* Likelihood ratio test */ 


\section{Annex 4: Test for functional form}

displayll_cd

-171.41016 (Log-likelihood value of Cobb- Douglas production function)

displayll_tl

-221.45927 (Log-likelihood value of translog production function)

display $-2 *\left(I I \_c d-I I \_t l\right) / *$ Likelihood ratio test */

$-100.09822$

Annex 5: Distribution of stochastic frontier model

displayll_cdhn

-159.0981 (Log-likelihood value half normal distribution)

displayll_cdtn

-156.80887 (Log-likelihood value of truncated normal distribution)

display -2*(II_cdhn - II_cdtn)/*Likelihood ratio test*/

\subsection{9}

Figures 


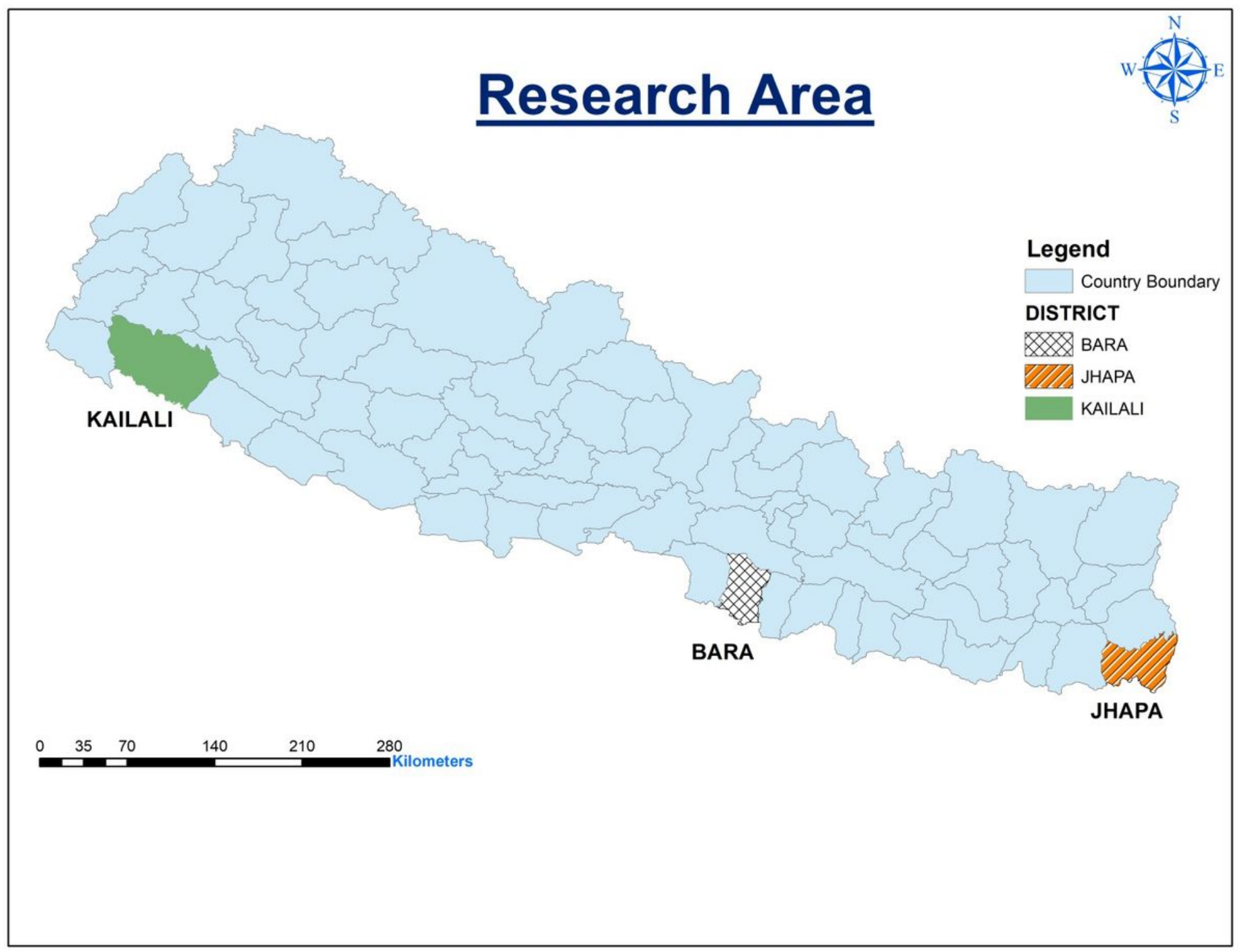

Figure 1

Research Area 